\title{
The Sovietization of Romania. Case-study: The Collectivization of Agriculture
}

\author{
Sanda Borșa \\ Phd, Researcher, "George Barițiu" Institute of History, \\ Romanian Academy, Cluj-Napoca, Romania
}

\section{Doi:10.5901/ajis.2013.v2n8p300}

\begin{abstract}
The present study entitled "The Sovietization of Romania. Case-study: the collectivization of agriculture" drawing on Romanian archive documentation and specialized literature proposes to reveal, based on processes and facts the main similarities and the minor differences existing between the institutional mechanisms involved in the collectivization of the Romanian agriculture and the Soviet model. In this attempt, by way of comparison I will analyse the Soviet model of Socialist transformation in agriculture against the Romanian one.
\end{abstract}

\section{The beginnings of Sovietization in Central and Eastern Europe}

As World War II was drawing to an end the relations between the three allies (the United States, Great Britain and the USSR) were growing increasingly tense, their rivalry leading eventually to the out-break of the Cold War. And yet, in 1945 the relations between the "Big Three" did not seem to anticipate such course of events. In February 1945 in Yalta they adopted the "Declaration on Liberated Europe" which stated that all territories previously under German control would have democratic elections. Later on, in July-August 1945 in Potsdam the allies also decided that the countries located in the geographical proximity of the USSR would have democratic governments and adopt a friendly behavior towards the USSR. ${ }^{1}$ In retrospect, one can say that the Soviets disregarded completely the agreements reached in Yalta and Potsdam.

The dissolution of the Comintern in 1943 was a measure taken by the Soviets in order to deceive Great Britain and the USA. In reality, the Kremlin was eager to engage in the Sovietization of Central and Eastern Europe, while keeping relations inside the "Big Three" group on good terms. Although the Comintern had been dissolved its tasks were taken over by the Department of International Information (Otdel Myezhdunarodnoi Informatzii). ${ }^{2}$ On the other hand, preserving the alliance of the "Big Three" was vital for the USSR as it had suffered important material and human losses (30 million dead, thousands of kilometers of roads and railways destroyed, tens of thousands of cities and villages ruined etc.) in World War II. ${ }^{3}$ In order to recover economically, not only did the USSR need financial assistance from its Western allies, but it had to win the British and the Americans on its side and press for heavy postwar reparations from Germany (as most of the German industry was located in the Allied occupation zones). ${ }^{4}$ The Soviet archives provide evidence as to the fact that decision-makers in the Kremlin called for continuous cooperation inside the "Big Three" alliance even after the war ended. ${ }^{5}$ At the same time, the USSR would carry further its plan to gain control over the Central and Eastern Europe

${ }^{1}$ R.J. Crampton, Eastern Europe in the Twentieth Century and After, Routledge, London, 2003, p.212

2 Eduard Mark, Revolution by Degrees. Stalin's National-Front Strategy for Europe 1941-1947, Working Paper, No. 31, Cold War International History Project, Washington DC, February 2001, p.6

${ }^{3}$ Geoffrey Roberts, The Soviet Union in World Politics: Coexistence, Revolution and Cold War, 1945-1991, Routledge, London, $1999, \mathrm{p}$. 17

4 Ibidem

5 Vladimir O. Pechatnov analysed five memoranda addressed to V. Molotov by Ivan Maisky ("Maisky's Memo", 10 January, 1944 ), Maxim Litvinov ("On the Relationship with the USA" 10 January 1945; "On the Prospects and the Basis of Soviet-British Cooperation", 15 November 1944; "On the Question of Blocs and Spheres of Influences", 11 January 1945) and Andrei Gromîko ("On the Question of Soviet-American Relations", 11 July 1944). A comparison of the five documents revealed a few common traits: the need to guarantee the security of the USSR; preserve the cooperation between the Big Three; create a 'Great Powers concert' based on "specific" share of the spheres of influence; the conviction that an Anglo-American antagonism will emerge. With respect to this matter, see Vladimir $O$. Pechatnov, The Big Three After World War II: New Documents on Soviet Thinking about Post War Relations with The United States and Great Britain, Working Paper, No. 13, Cold War International History Project, Washington DC, May 1995, pp.1-17 
countries. The Soviet Department of International Information adopted the provisions laid down by the Comintern in the so called National Front Strategy and made slight additions so as not to raise suspicions from the Americans and the British. The National Front Strategy had planned to create national fronts in the countries of Central and Eastern Europe consisting of representatives of the workers, the peasants, the intellectuals and the "small bourgeoisie". The mission of the national fronts was to promote a political vision urging for reforms in agriculture (aimed at gaining the sympathy of the peasantry) and for setting up a "mixed" economy which involved the nationalization of large industries and the survival of small private businesses. The latter was intended by the Kremlin in order to gain support from the "small bourgeoisie". 6

Eventually, the National Front Strategy proved to be sterile as non-communist leaders openly refuted participation in government coalitions dominated by the Communists. ${ }^{7}$ Faced with this failure, the decision-makers in the Kremlin decided to set up fraudulent elections in the countries of Central and Eastern Europe and enforce the rule of "people's democracies" in this geographical area. ${ }^{8}$ But this decision had a negative impact on the relations between the "Big Three" which began to worsen progressively, leading to a Cold War between the former allies. The newly created "people's democracies", imposed by the Soviets in Europe, copied ad-litteram the Soviet political, economic, cultural and social model.

\title{
2. Enforcing collectivization in Romania
}

The collectivization of the Romanian agriculture was launched at the Plenary of the Central Committee (CC) of the Romanian Workers' Party (RWP) on March 3-5, 1949 as a simulation of the collectivization pursued by the Soviet Union. Firm evidence in this respect was the transplantation and enforcement of institutions specific of the collectivization from the Soviet Union into the Romanian People's Republic (RPR). Hence, the Soviet kolkhoz (collective farm) equaled a collective agricultural farm (Gospodăria Agricolă Colectivă) in the RPR; the Soviet sovkhoz (state farm) equaled the Romanian state agricultural farm (Gospodăria Agricolă de Stat); the Soviet TOZ were adopted and developed as agricultural associations of peasants (întovărăşirı) in Romania; the Soviet MTS (mashinno-traktornaia stantsiia) equaled the Romanian machine and tractor stations (SMT - Staţiuni De Maşini Şi Tractoare). ${ }^{9}$

According to Gheorghe Gheorghiu-Dej, the Romanian communist leader, at that time the enforcement of the Soviet institutional model in the Romanian agriculture was absolutely necessary because, he argued, the "Soviet agriculture based on collective agricultural farming is the most productive in the world" and the transition to the 'great agriculture' the Socialist one - must follow the same pattern:

\begin{abstract}
"Comrade Stalin has shown us that there are two ways: one is the capitalist and leads to the impoverishment of the poor and middle-range peasantry ... and the other one is the Socialist - it's the path to the unification of small and medium-size individual households into large collective farms, in other words it represents a communion of the poor and middle-range peasants in a common effort, the collective labor in view of raising the material and cultural living of the hard working people. Of course, between the two options, the Socialist path in agriculture is the only one which serves the goals of the working class and the interests of the poor and middle-range peasantry."10
\end{abstract}

State farms, the so-called sovkhoz, took shape in the USSR since the time of the civil war - although in a small number - on the former properties of Russian landlords. ${ }^{11}$ In Romania, the Administration of the Agricultural, Zoo technical, Industrial and Fieldwork Machine Capital [Regia Exploatărilor Agricole, Zootehnice, Industriale şi de Maşini agricole (REAZIM)] was set up in 1946 and one year later transformed into the Administration of State Farms and Machine Stations [Administraţia Fermelor de Stat şi a Staţiunilor de Maşini (AFSM)]. In the fall of 1948 the AFSM was reorganized into two separate units: the state agricultural farms (Gospodăriile Agricole de Stat - GAS) and the machine and tractor stations (Staţiunile de Maşini şi Tractoare - SMT). The split between the two units was a measure which

\footnotetext{
${ }^{6}$ Eduard Mark, op.cit., pp.17-19

${ }^{7}$ Ibidem, p.39

${ }^{8}$ Archie Brown, The Rise and Fall of Communism, Harper Collins Publishers, New York, 2009, p.167

9 Dan Cătănuş, Octavian Roske, Colectivizarea agriculturii în România. Dimensiunea politică, Vol. I, 1949-1953, Institutul Naţional pentru Studiul Totalitarismului, Bucureşti, 2000, p. 13

${ }^{10}$ Gheorghe Gheorghiu -Dej, Articole şi cuvântări, Editura Partidului Muncitoresc Român, 1951, pp. 257-258

${ }^{11}$ Sanda Borşa, Mihai Croitor, Colectivizarea agriculturii în România: mecanismele legislative ale subordonării lumii rurale (1949-1962), Mega, Cluj-Napoca, 2009, p. 11
} 
anticipated the beginning of collectivization of the Romanian agriculture pursued by the Communist regime in 1949.12

According to archive evidence, on April 11, 1949 in Romania there were 693 state agricultural farms (GAS) ${ }^{13}$ meant to "become model farm which would convince the working peasantry of the superiority of the Socialist agriculture over the private fragmented agriculture, to act as strong agriculture development centers providing the collective farms, the agricultural associations and the working peasants with selected seeds, to experiment new plant varieties and new labor methods in agriculture, to breed cattle for reproduction, as well as to provide the market with the agricultural produce and the industry with raw materials"14. For these reasons, the Romanian communist regime believed that these new collective farms would have to "enforce the Soviet agro technical and zoo technical norms and apply the precious experience of the sovkhoz"15. At the same time, by recognizing the "invaluable help from the Soviet Union", the support of the RWP, and the efforts of the GOSTAT workers, in 1949 the Romanian communist regime admitted that the state agricultural farmss (GAS) were "the most important Socialist element in agriculture". ${ }^{16} \mathrm{It}$ is interesting to see how the workers in the sovkhoz and in the GAS were remunerated: while a sovkhoz member gained minimum wage without receiving any agricultural produce or profit share from the sale of these products ${ }^{17}$, in the Romanian state agricultural household the social relations were based on labor contracts which stated that the employees were remunerated "according to the Socialist principle based on wage and material joint interest". ${ }^{8} \mathrm{It}$ is worth noting that the organization of the collective agricultural farmss in Romania which simulated the Soviet sovkhoz received significant support from the Soviet counselors from the Romanian Ministry of Agriculture. ${ }^{19}$

In 1948, 87 machine and tractor stations (SMT) were set up in Romania. ${ }^{20}$ It is worth noting that in 1949 one SMT owned on average 39 tractor ploughs, 44 agricultural tractors (15 horse power each) and 31 threshing machines. ${ }^{21}$ Similar to the state agricultural farms (GAS), the SMT had a well defined role, as stated in archive documents:

"The machine and tractor stations have the role to introduce advanced technologies in agriculture, to pull the working peasantry from under the rule of the chiaburi [kulaks] and to persuade them of the superiority of mechanical farming on large areas of arable land, thus stimulating and assisting them in setting up agricultural associations and collective farmss, by providing them with proper mechanical tools and practical agro technical advice; the SMT must provide permanent multilateral assistance and consolidate the collective farms economically, and support the different forms of peasant associations in view of transforming them into collective farms."22

Referring back to the Soviet model, a decree issued on November 2, 1918 had ordered the creation of three types of collective farms besides the sovkhoz: the TOZ, the ARTEL and the COMMUNE. ${ }^{23}$ Thus, unlike the so called "backward individual farms" specific of the Tsarist era, the collective farms (kolkhoz) were considered superior institutions consisting of three evolution stages: the TOZ (Tovarishchestvo po sovmestnoi obrabotke zemli) was mainly an association in which land was collective property toiled by its members in common, and the produce they received was proportional to the size of the arable land they brought in the collective farm; the ARTEL marked the transition from the TOZ to the COMMUNE: the members shared the labor of the land although private property was formally recognised, and the means of production were collectively-owned; the COMMUNE (Kommuna) was a superior form of organisation of the Soviet agriculture in which everything was collective property, including goods, land and produce, the latter being shared equally

\footnotetext{
12 See Gheorghe lancu, Virgiliu Ţârău, Ottmar Traşcă, Colectivizarea agriculturii în România. Aspecte legislative 1945-1962, Presa Universitară Clujeană, Cluj-Napoca, 2000, p. XV; Dumitru Şandru, Reforma agrară din 1945 în România, Institutul Naţional pentru Studiul Totalitarismului, Bucureşti, 2000, pp. 186-187

13 The National Central Historical Archives (ANIC), Fond CC al PCR - Secţia Agrară, dos. 1/1949, ff.1-3

${ }^{14}$ ANIC, Fond CC al PCR - Secţia Agrară, dos. 45/1952, f. 3

15 Ibidem

${ }^{16}$ ANIC, Fond CC al PCR - Secția Agrară, dos. 65/1949, f. 14

${ }_{17}$ See Mark Sandle, Communism, Longman, London, 2006, pp. 91-92; Sheila Fitzpatrick (ed), Stalinism: new directions, Routledge, London, 2000, p. XVII

${ }^{18}$ Ernest Lupan, Drept colectivist agricol, Editura Didactică şi Pedagogică, Bucureşti, 1964, p. 42

${ }^{19}$ For a more detailed perspective of the GAS, see Nicoleta Ionescu-Gură, Stalinizarea României. Republica Populară Română: 19481950: transformări instituţionale, BIC ALL, Bucureşti, 2005, pp. 509-526

20 Octavian Roske, „Radiografia unui eşec. Colectivizarea agriculturii în România”, in Ruxandra Ivan (coordinator), „Transformarea socialistă": politici ale regimului comunist între ideologie şi administraţie, Polirom, Iaşi, 2009, p.87

${ }^{21}$ Ibidem

${ }^{22}$ ANIC, Fond CC al PCR - Secţia Agrară, dos. 45/1952, f. 3

${ }^{23}$ Mark Sandle, A Short History of Soviet Socialism, UCL Press, London, 1999, p.83
} 
between members. ${ }^{24}$

As for the process of collectivization in Romania, the agricultural associations of peasants (întovărăşiri) were set up in line with the 1952 model-statute which stated that "land would be to worked in shared custody using the tractors and machines provided by the SMT, the cattle and agricultural inventory would be used rationally, and advanced agro technical methods involving deep ploughing, the use of selected conditioned seeds and fertilizers, and fighting weeds and pests would be introduced" (article 2). ${ }^{25}$ Members would submit all arable land owned or only part of it without losing property over this land. Instead, the individual plots were merged into larger fields. The livestock and the farm tools would remain in the patrimony of the peasants, although most of the fieldwork was carried out in common. However, the income was split between members according to the size of the land submitted to the association by each individual. ${ }^{26}$

In this context the propaganda carried out by the Scânteia newspaper ("organ of the Central Committee of the RWP") referring to the creation of agricultural associations of peasants (întovărăşiri) was illustrative:

\section{"[...] it has an important role in consolidating the alliance between the working class and the working peasantry because it is a form of support provided by the working class to the poor and middle-range peasants, in order to liberate themselves from the economic rule of the chiaburi, to use the state's tractors and machines and to improve their living standards". ${ }^{27}$}

In the same logic of the transplantation and enforcement of the collectivization institutions in Romania were created the agricultural production cooperatives with rente (CAP). Unlike the agricultural associations of peasants, article 3 of the model-statute stated that "the members of the CAP would submit the entire land owned by themselves and by family members, as well as any piece of land they might obtain afterwards through inheritance, donation or by any other means, except for the land under the house, the household appendices and the yard, and for 20-30 ares of land which remained in their property." ${ }^{28}$ However, article 4 stated that the entire land submitted to the CAP would remain in the patrimony of its members. According to article 5, CAP members were supposed to pool all their livestock and farm inventory together in the CAP. Fieldwork would be performed collectively (article 12) and once the cooperative paid all financial dues, "at least $75 \%$ of the remaining cash income would be split between members in proportion to the number of workdays and up to $25 \%$ according to the size, the quality and the usage of the land submitted" (articles 18 and 19). ${ }^{29}$ Thus, the CAP was an inferior institution as compared to the collective household, and yet superior to the agricultural associations of peasants. ${ }^{30}$

In the Soviet kolkhoz, which inspired the creation of the Romanian collective agricultural farms (GAC), the 1935 model-statute stated that the land remained permanently under the control of the kolkhoz, although its members were allowed to own a small piece of land to ensure their subsistence. Also, the members of the kolkhoz could rent the horses used in the kolkhoz in order to work their own land. Hence, the 1935 statute legalized private property over small pieces of land. ${ }^{31}$ The Romanian GAC was considered a "superior form of cooperation in agricultural production", more evolved than the agricultural associations of peasants and the CAP32. According to article 4 of the 1949 model-statute, the GAC members had to submit their land to the collective patrimony of the GAC: "each peasant household joining the GAC would own a land around the house to be used as yard, garden, vineyard or orchard no larger than ...... hectares for personal use. (Considering local specificities, the size could vary between 1/4 and 1/2 excluding the area covered by

\footnotetext{
24 Ibidem; "Document 52. Decree of the CC of the $\operatorname{VKP}(b)$ on the pace of collectivization and state assistance to collective-farm construction, 5 January 1930", in Lynne Viola, V. P. Danilov, N. A. Ivnitskii, Denis Kozlov (editors) The War Against the Peasantry, 1927-1930. The Tragedy of the Soviet Countryside, Yale University Press, London, 2005, pp. 201-204

${ }^{25}$ Official Bulletin of the Romanian People's Republic, no. 6, 25 January 1952, p. 10

${ }^{26}$ See Ernest Lupan, op. cit., pp. 50-51

27 „Organizarea întovărăşirilor agricole - sarcină de frunte”, in Scânteia, year XXI, no. 2376, 17 June 1952, p. 1

${ }^{28}$ ANIC, Fond CC al PCR - Cancelarie, dos. 102/1956, f. 62

29 Ibidem, ff.62-63, 66-68

30 For a more detailed perspective on the agricultural production cooperative (CAP), see Linda Miller, „Drept şi propagandă: posesia asupra terenurilor agricole, colectivizarea şi proprietatea socialistă”, in Dorin Dobrincu, Constantin Iordachi (editors), Ţărănimea şi puterea. Procesul de colectivizare a agriculturii în România (1949-1962), Polirom, laşi, 2005, p. 145; Ernest Lupan, op. cit., pp. 25, 51; Sanda Borşa, Mihai Croitor, op. cit., pp. 109-111

31 Lynne Viola, Peasant Rebels Under Stalin: Collectivization and the Culture of Peasant Resistance, Oxford University Press, New York, 1996, pp.231-233; see also Sheila Fitzpatrick, Stalin's Peasants: resistance and survival in the Russian village after collectivization, Oxford University Press, New York, 1996, p.112

${ }^{32}$ Ernest Lupan, op. cit., p. 52
} 
buildings, and up to 1 hectare in regions with plenty of arable land (article 5)". ${ }^{33}$ Article 4 of the model-statute adopted by Decision no. 1650/1953 of the Council of Ministers stated that "GAC members would submit all arable land to the collective patrimony of the GAC" and, according to article 5, "each member of the GAC would own 20-30 ares of land to be used as yard, garden or orchard, excluding the area covered by buildings." Also, members were forced to submit their livestock and farm inventory, with a few exceptions (articles 7 and 8). ${ }^{34}$

At the beginning of forced collectivization in the USSR, the members of the Soviet kolkhoz were not remunerated according to the workday system. Instead, after the kolkhoz had submitted the quotas to the centre, paid the SMT and put aside the seed reserve for the following year, each family would receive a quota share in proportion to the number of family members. The remuneration per workday was introduced in 1931. However, this system did not use weekdays as reference..$^{35}$ Article 26 of the 1953 model-statute laid down the provisions concerning remuneration for labor in the Romanian GAC:

"Fieldwork in collective farms will be carried out based on agreement. Observing the recommendations put forward by the Minister of Agriculture, the Board of the GAC will submit for approval to the general assembly the labor norms for all types of fieldwork and their evaluation in terms of workdays". Also, "the split of income between the members of the collective household is based exclusively on the number of workdays performed by each individual" (article 27) ${ }^{36}$.

\section{Conclusion}

In conclusion, the Soviet model of agricultural collectivization was taken over almost ad-litteram by the Romanian authorities. The minor differences which defined the two models were determined by local specificities.

\section{Acnkowledgement}

This work was supported by a grant of the Romanian National Authority for Scientific Research, CNCS - UEFISCDI, project number PN-II-RU-PD-2011-3-0030

We mention the fact that this article is a part of a broader research project entitled: "Between Propaganda and Repression: the Collectivization of the Romanian Agriculture and the Metamorphoses of the Rural World (1949-1962)"

\section{References}

Borşa, Sanda, Croitor, Mihai, Colectivizarea agriculturii în România: mecanismele legislative ale subordonării lumii rurale (1949-1962), Mega, Cluj-Napoca, 2009;

Brown, Archie, The Rise and Fall of Communism, Harper Collins Publishers, New York, 2009;

Cătănuş, Dan, Roske, Octavian, Colectivizarea agriculturii în România. Dimensiunea politică, Vol. I, 1949-1953, Institutul Naţional pentru Studiul Totalitarismului, Bucureşti, 2000;

Collection of decisions and provisions of the Council of Ministers of the Romanian People's Republic, no. 39, 18 June 1953;

Crampton, R.J., Eastern Europe in the Twentieth Century and After, Routledge, London, 2003;

Fitzpatrick, Sheila (ed), Stalinism: new directions, Routledge, London, 2000;

Eadem, Stalin's Peasants: resistance and survival in the Russian village after collectivization, Oxford University Press, New York, 1996;

Gheorghiu -Dej, Gheorghe, Articole şi cuvântări, Editura Partidului Muncitoresc Român, 1951;

lancu, Gheorghe, Târău, Virgiliu, Traşcă, Ottmar, Colectivizarea agriculturii în România. Aspecte legislative 1945-1962, Presa Universitară Clujeană, Cluj-Napoca, 2000;

Ionescu-Gură, Nicoleta, Stalinizarea României. Republica Populară Română: 1948-1950: transformări instituţionale, BIC ALL, Bucureşti, 2005;

Lupan, Ernest, Drept colectivist agricol, Editura Didactică şi Pedagogică, Bucureşti, 1964;

Mark, Eduard, Revolution by Degrees. Stalin's National-Front Strategy for Europe 1941-1947, Working Paper, No. 31, Cold War International History Project, Washington DC, February 2001;

${ }^{33}$ ANIC, Fond CC al PCR - Secţia Agrară, dos. 16/1949, ff. 1-2

${ }^{34}$ Collection of decisions and provisions of the Council of Ministers of the Romanian People's Republic (further on, CHD), no. 39, 18 June 1953, pp. 751-753

${ }^{35}$ See Lynne Viola, op. cit., pp. 207-208; Sheila Fitzpatrick, Stalin's Peasants: resistance and survival in the Russian village after collectivization, p.190

${ }^{36}$ CHD, no. 39, 18 June 1953, pp. 758-760; see also Ernest Lupan, op. cit., pp. 237-250 
Miller, Linda, „Drept şi propagandă: posesia asupra terenurilor agricole, colectivizarea şi proprietatea socialistă”, in Dorin Dobrincu, Constantin lordachi (editors), Tărănimea şi puterea. Procesul de colectivizare a agriculturii în România (1949-1962), Polirom, Iaşi, 2005, pp.136-153;

Official Bulletin of the Romanian People's Republic, no. 6, 25 January 1952;

Pechatnov, O. Vladimir, The Big Three After World War II: New Documents on Soviet Thinking about Post War Relations with The United States and Great Britain, Working Paper, No. 13, Cold War International History Project, Washington DC, May 1995;

Roberts, Geoffrey, The Soviet Union in World Politics: Coexistence, Revolution and Cold War, 1945-1991, Routledge, London, 1999;

Roske, Octavian, „Radiografia unui eşec. Colectivizarea agriculturii în România”, in Ruxandra Ivan (coordinator), "Transformarea socialistă": politici ale regimului comunist între ideologie şi administraţie, Polirom, Iaşi, 2009, pp.77-107;

Sandle, Mark,Communism, Longman, London, 2006, pp. 91-92;

Idem, A Short History of Soviet Socialism, UCL Press, London, 1999

Scânteia, year XXI, no. 2376, 17 June 1952;

Şandru, Dumitru, Reforma agrară din 1945 în România, Institutul Naţional pentru Studiul Totalitarismului, Bucureşti, 2000;

The National Central Historical Archives (ANIC), Fond CC al PCR - Secţia Agrară, dos. 1/1949, dos. 16/1949, dos. 45/1952, dos. 65/1949; Fond CC al PCR - Cancelarie, dos. 102/1956;

Viola, Lynne, Danilov, V. P., Ivnitskii N. A., Kozlov, Denis (editors) The War Against the Peasantry, 1927-1930. The Tragedy of the Soviet Countryside, Yale University Press, London, 2005;

Viola, Lynne, Peasant Rebels Under Stalin: Collectivization and the Culture of Peasant Resistance, Oxford University Press, New York, 1996. 